\title{
Competitiveness of the Agricultural Sector as a Factor in Improving Food Security in the Conditions of Globalization
}

\author{
Serik Sarsengalievich Ospanov ${ }^{1}$, Assem Yermekovna Kaliyeva ${ }^{1}$, Raushan Tlegenovna Dulambaeva ${ }^{1}$, Zhanar \\ Yahiyaevna Aubakirova ${ }^{1} \&$ Talgat Pazilbekovich Tabeev ${ }^{1}$ \\ ${ }^{1}$ Al-Farabi Kazakh National University, Almaty, Kazakhstan \\ Correspondence: Assem Yermekovna Kaliyeva, Aiteke bi street, 194, apartment 21, Almaty, 050026, Republic \\ of Kazakhstan. Tel: 8-727-225-3844. E-mail: assemkalieva@gmail.com
}

\author{
Received: March 19, 2015 Accepted: April 21, 2015 Online Published: May 14, 2015 \\ doi:10.5539/res.v7n7p307 URL: http://dx.doi.org/10.5539/res.v7n7p307
}

\begin{abstract}
This article is devoted toan analysis of agricultural sector of the country which is considered both a factor of ensuring competitiveness of national economy in general, and a factor of ensuring food security within the country. In the article devoted to an analysis of competitiveness of the country's agriculture in the age of globalization, including conditions of regional integration into the Customs union (CU) on the basis of statistical data. Also the problems and prospects of Kazakhstan's agricultural sector are studied, examples of factors impeding the competitiveness of the agro-industrial complex (AIC) of Kazakhstan and opportunities in this sector are also provided. In order to assess the competitiveness of the countryэs agriculture in the framework of regional integration, we have analyzed such factors as: the structure of mutual trade of the CU's member-countries by main commodity groups (including separately for mutual trade of agricultural products) and Kazakhstan's share in it; production and yield of crops and livestock products, their effectiveness (assessment of the level of agricultural output per 1 engaged in this sector); government support and subsidies for farmers, as well as absolute and relative values of investment volumes in Kazakhstan's AIC. The study revealed that Kazakhstan's share in the CU food market is insignificant, and also the low competitiveness of domestic agriculture, due to the constraints and problems limiting development of the agricultural sector. In order to improve the competitiveness of Kazakh products in the CU food market and increase its share problem-solving recommendations are provided in the article.
\end{abstract}

Keywords: food security, globalization, integration, agriculture, competitiveness, agricultural products, production

\section{Introduction}

Today, in the age of increasing globalization and fast-growing integration, a role of regional cooperation within economic zones and Customs unions is becoming more prominent. Such associations, in turn, provide a more effective interaction of participating countries and create new opportunities for them. In other words, globalization forces to unite- "nowadays international economic relations are becoming the main form of the very existence of all parts of the world economy, as separate business entities on the territory of national economic systems, so economic systems themselves" (Berentaev, 2013).

In 2010 the Customs Union (CU) was formed at the initiative of three states-Kazakhstan, Russia and Belarus. Eurasian Economic Union (EAEC) of Armenia, Belarus, Kazakhstan and Russia operates on its base since January 1, 2015.

From the moment of the CU's formation, indicators of foreign trade have grown, and that favorably affects economies of member-countries in general. In addition, the competition in the common food market and the market of agricultural raw materials increased. At the same time, despite the general increase in indicators of mutual trade of the $\mathrm{CU}$ member-countries and foreign trade with the third countries, experts note the tendency of decrease in share of the CU countries in export of Kazakhstan production, and, vice versa, increase in their share in goods deliveries in the Kazakhstan market. In this regard, the questions concerning strengthening of competitiveness of domestic, agricultural, and food production in the $\mathrm{CU}$ food market are actual. 


\section{Literature Review}

Globalization and its various aspects are one of the most relevant topics and concepts in scientific knowledge of the past decades. Despite the fact that a sufficient number of researchers relate the concept of "globalization" to the modern phenomena (systematically the concept began to be used since the eighties), there is another group of scientists who believe that the origin of globalization lies in the Middle Ages, and perhaps in earlier times (Kuzovkov, 2010). In turn, there are scholars, such as Immanuel Wallerstein, who believe that the globalization process flows for over 500 years (Wallerstein, 2000). In spite of the difference between the interpretations of the nature of globalization, basically scientists agree that "globalization - is a process of development and increment of interrelation and interdependence of economic entities of different levels (countries, companies, etc.)."

In turn, the concept of integration is similar. Some scholars distinguish between these two terms, saying that "integration is a process of strengthening the relationship between two or more parties (countries)", and "globalization is a unified system of relations that is not limited by national boundaries" (Evdokimov, 2005). Another category of scientists believe that these processes are consistent: "Regional economic integration is a factor contributing to the development of globalization, because it creates the conditions for free circulation of goods, services, capital and labor, which leads to increased interconnection and interdependence of economies, creation of single world market" (Kiselev, 2009). Also, according to Vladimirova I. G. "economic integration is a core of globalization and globalization itself is the next step after the international economic integration and represents a higher stage of internationalization" (Vladimirov, 2001). In general, the study of the integration processes, as well as its various aspects in economic theory is focused on a number of works of such scholars as W. Röpke, M. Allais, B. Balas, C. Rolf, Eugene Rostow, G. Myrdal, J. Tinbergen, J. Weiner, D. Mead, and R. Mundell. In turn, among the works devoted to the study of the integration processes and their directions on the post-Soviet space works of A. Liebman can be distinguished (Libman, 2012).

\section{Methods}

In the process of writing article empirical and theoretical methods of scientific research were used, such as the method of scientific abstraction, methods of analysis and synthesis, comparative and statistical analysis, induction and deduction.

According to the method of scientific abstraction in the article attention is concentrated on the study of indicators of the country's agricultural sector and food security of Kazakhstan in the framework of such integration association as CU. According to the methods of analysis and synthesis, comparative and statistical analysis various parameters characterizing the state and level of development of the agricultural sectors of the CU member countries were investigated. The structure of mutual trade between the participants and their share in it, indicators of crop yields and livestock production and agribusiness in general, indicators of the level of efficiency of agricultural production in member-countries, as well as the level of government support and subsidies for farmers were considered as the main indicators of the study.

In turn, to achieve results and develop recommendations on improvement of the index competitiveness of Kazakhstan's AIC methods of system analysis were used, which means the set of research methods, and other general theoretical analysis tools, such as the collection and generalization of indicators, methods of induction and deduction.

\section{Results}

Trade relations between member-countries were significantly changed when Customs union started functioning. In this regard, for 2010-2013 the general mutual commodity turnover increased from 47.1 billion USD to 64.1 billion USD. In turn, for the first half of 2014 indicators of mutual commodity turnover amounted to 32.8 billion USD that is $10.7 \%$ less than in the relevant period of 2013 . The decrease in mutual commodity turnover over the specified period occurred due to reduction of mutual trade of metals and metal products (reducing by $27 \%$ ), rawhide and articles made from it (reducing by 24.5\%), mineral products (reducing by $13 \%$ ), production of chemical industry (reducing by $9.9 \%$ ), cars, equipment and vehicles (reducing by $7.9 \%$ ), food and agricultural products (reducing by - 4.7\%) (Statistical data of the Eurasian Economic Commission, 2014).

At the same time it should be mentioned that the main share in structure of mutual trade between the $\mathrm{CU}$ member-countries is made by mineral products, which account for $32.7 \%$ of the general commodity turnover or 10.7 billion USD in January - July, 2014. In turn, the share of agricultural trade account for $13.6 \%$ of the general commodity turnover (Figure 1). 


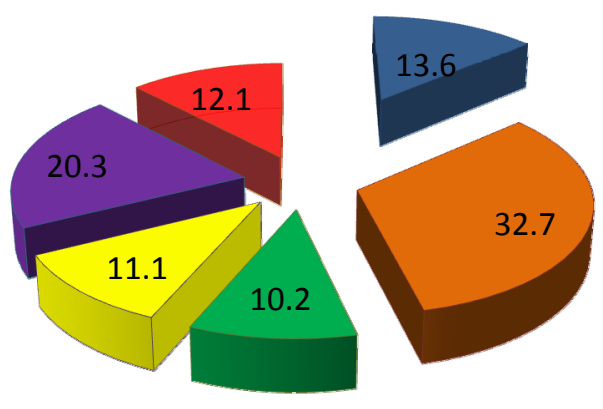

Food products and agricultural raw materials

$\square$ Mineral products

Chemical industry products

$\square$ Metals and products from them

Machinery, equipment and vehicles

Other products

Figure 1. Structure of mutual trade of the CU member-countries in main commodity groups in January-March, 2014, in percentage terms (Statistical data of the Eurasian Economic Commission, 2014)

Despite fluctuations in mutual trade between the CU member-countries, dynamics of agricultural trade has a positive trend in 2010-2013. Therefore, indicators of mutual trade in these products increased from 4.8billion USD in 2010 to 8.2 billion USD in 2013 (Figure 2). For January-July of the current year this indicator amounted to 4.5 billion USD.

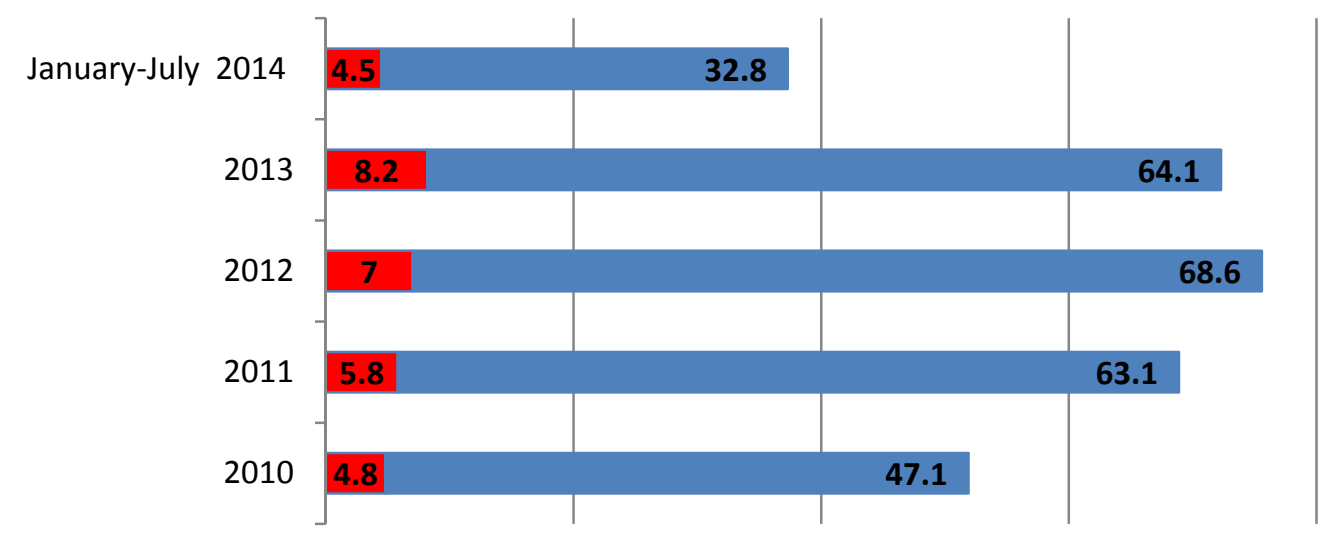

The mutual trade in food and agricultural products

The total amount of of mutual trade

Figure 2. Structure of mutual trade of the CU member-countries in main commodity groups, in billion USD (Statistical data of the Eurasian Economic Commission, 2014)

It should be noted that the main share of mutual agricultural trade in the Customs union market is a share of the Republic of Belarus which accounts for $60.4 \%$ of food products in the CU market. The main articles of the RB export to the CU countries are meat and meat by-products, dairy products, eggs, honey (Structure of mutual trade of the CU and the EEC member-countries, 2014). In turn, the share of Kazakhstan in mutual agricultural trade in the Customs union market in January-July, 2014 amounted less than to 4\% or 177.1 million USD, that is 15 times lower than volumes of the Belarusian deliveries, and in 9 times lower than Russian ones. 
Table 1. Mutual trade of production of the CU agrarian and industrial complex (January-July, 2014, million USD)

\begin{tabular}{|c|c|c|c|c|c|c|c|}
\hline \multirow[b]{2}{*}{$\begin{array}{l}\text { Name of the commodity } \\
\text { group }\end{array}$} & \multirow[b]{2}{*}{$\begin{array}{l}\text { The } \mathrm{CU} \text { and } \\
\text { the EEC-in } \\
\text { total }\end{array}$} & \multicolumn{6}{|c|}{ Including } \\
\hline & & The RB & $\begin{array}{l}\text { Share in } \\
\text { total } \\
\text { amount, } \\
\%\end{array}$ & The RK & $\begin{array}{l}\text { Share in } \\
\text { total } \\
\text { amount, } \\
\%\end{array}$ & The RF & $\begin{array}{l}\text { Share in } \\
\text { total } \\
\text { amount, } \\
\%\end{array}$ \\
\hline $\begin{array}{l}\text { Total amount, in all } \\
\text { commodity } \\
\text { including: }\end{array}$ & 32857.8 & 9502.1 & 28.9 & 2915.2 & 8.9 & 20440.5 & 62.2 \\
\hline Agricultural products & 4482.8 & 2708.7 & 60.4 & 177.1 & 3.9 & 1596.9 & 35.6 \\
\hline $\begin{array}{l}\text { Dynamics as a percentage by } \\
\text { the relevant period of } 2013 \text {. }\end{array}$ & 95.3 & 96.6 & - & 52.3 & - & 102.2 & - \\
\hline
\end{tabular}

Compiled by the author by "Structure of mutual trade of the CU and the EEC member-countries, 2014"

Therefore, nowadays the share of Kazakhstan in the CU food market doesn't exceed 4\%. In our opinion, this situation is caused by low volumes of agricultural products within the country. So, in the first half of 2014 the gross output of agricultural products in Kazakhstan amounted to 3.2 billion USD or $8.1 \%$ of total amount of the agricultural products of the CU member-countries (Table 2).

Table 2. Production of agricultural products of the CU member-countries (the 1st half of 2014)

\begin{tabular}{lll}
\hline & \multicolumn{1}{c}{ Agricultural products } \\
\cline { 2 - 3 } & million USD & $\begin{array}{l}\text { as a percentage of the 1st half of } \\
\mathbf{2 0 1 4}\end{array}$ \\
\hline Total amount, in the CU countries & & \\
Including & $\mathbf{3 9 . 3}$ & $\mathbf{1 0 1 . 0}$ \\
The RepublicofBelarus & 3.8 & 95.7 \\
The RepublicofKazakhstan & 3.2 & 103.3 \\
The RussianFederation & 32.3 & 101.4
\end{tabular}

Report of EEC "Production performance of agriculture of the CU and the EEC member-countries at the end of the 1 st half of $2014 "$

Also indicators of productivity and yields of the main agricultural productions in the RK are lower in comparison with other member-countries of the CU. For instance, in spite of the fact that in 2013 indicators of the basic crops yields in Kazakhstan increased in comparison with 2012, the level of these indicators, in most cases, are lower than performance levels of crops in Russia and Belarus (Figure 3).

As is seen from figure 3, in 2013 the basic crops yields in Kazakhstan increased in comparison with 2012. But despite it, Kazakhstan outruns Russia only in yields of vegetables and potatoes, and Belarus in productivity of vegetables to a small extent. 
Grains crops

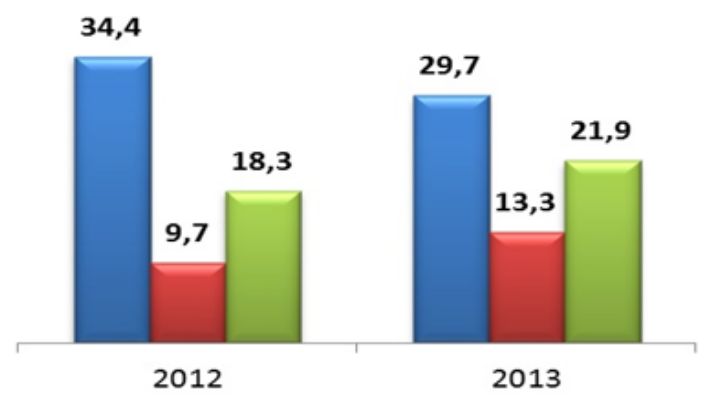

Potato

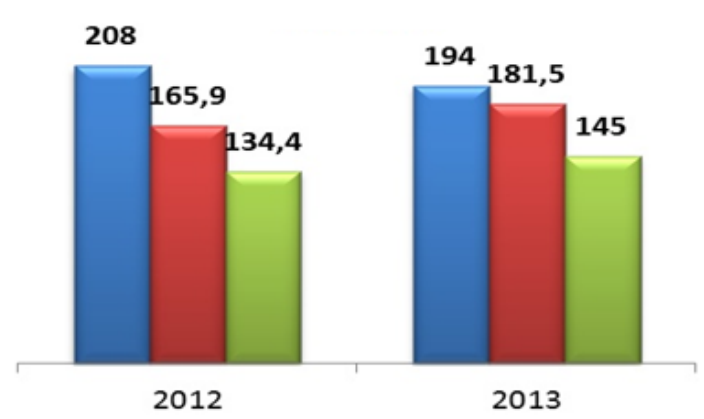

Sugar beet

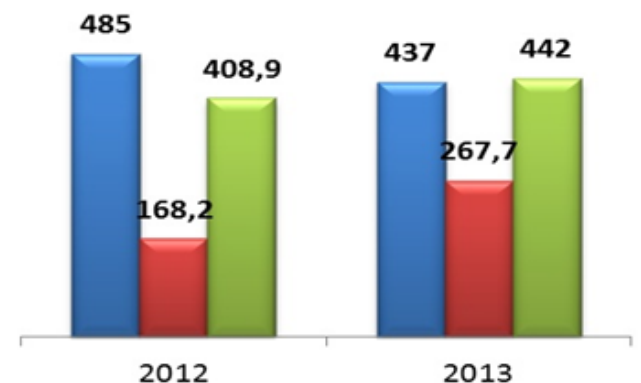

Vegetables

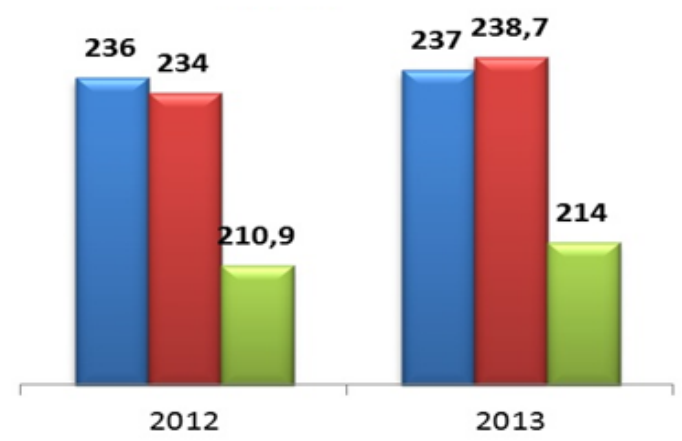

The Republic of Belarus $\quad \square$ The Republic of Kazakhstan $\square$ The Russian Federation

Figure 3. The basic crops yields in the CU countries, in 2012-2013, dt/ha ("Analysis of production performance of agricultural and food products of the CU and the EEC member-countries for 2012-2013”, 2014)

Also the share of Kazakhstan within the $\mathrm{CU}$ is low in production of livestock products. At the same time, production of livestock products increased in Kazakhstan in the first half of 2014 in comparison with the relevant period of 2013. For example, production of cattle and poultry increased for $3.7 \%$ and amounted to 714.9 thousand tons, milk and eggs production increased by $2.2 \%$ and $6.6 \%$ respectively (amounted to 2,485.6 thousand tons and 2,024.4 million units respectively). However, despite increase in production of livestock products, the share of Kazakhstan in this category remains insignificant and amounted to $10 \%$ of total production of livestock products of the CU member-countries (Table 3).

Table 3. Production of livestock products in the first half of 2014 in the CU member-countries (thousand tons)

\begin{tabular}{|c|c|c|c|c|c|c|c|}
\hline & \multirow[b]{2}{*}{$\begin{array}{l}\text { The CU and } \\
\text { the EEC-in } \\
\text { total }\end{array}$} & \multicolumn{6}{|c|}{ Including } \\
\hline & & The RB & $\begin{array}{l}\text { Shareinto } \\
\text { talamount } \\
, \%\end{array}$ & The RK & $\begin{array}{l}\text { Shareinto } \\
\text { talamount } \\
, \%\end{array}$ & The RF & $\begin{array}{l}\text { Shareinto } \\
\text { talamount } \\
, \%\end{array}$ \\
\hline Cattle and poultry & 7,006 & 781.8 & 11.2 & 714.9 & 10.2 & $5,509.0$ & 78.6 \\
\hline Milk & 20,855 & $3,315.7$ & 15.9 & $2,485.6$ & 11.9 & $15,054.1$ & 72.2 \\
\hline Eggs, million units & 24,470 & $1,997.5$ & 8.2 & $2,024.4$ & 8.2 & $20,448.5$ & 83.6 \\
\hline
\end{tabular}

Report of EEC "Production performance of agriculture of the CU and the EEC member-countries at the end of the 1 st half of 2014 "

Certainly, a tenfold gap in indicators of Kazakhstan with ones of the Russian Federation can be explained by the fact that each member-country has developed its own CU structure of agricultural production, primarily due to 
objective differences in climatic conditions. In addition, there are differences in the size and structure of state support for national agro-industrial complexes. These factors have a direct impact on the AIC development and agricultural production in these countries. However, if that trend continues, it will be a direct threat to national producers of agricultural production, for whom it is difficult to compete with Belarusian and Russian colleagues.

\section{Discussion}

The sectors of Kazakhstan agro-industrial complex possessing a considerable export potential and capable to provide high competitiveness of the RK agro sphere within the $\mathrm{CU}$, in our opinion, are represented by: livestock husbandry, grain-growing, and food industry.

One of the main factors of successful development of these sectors in the RK is an availability of croplands. It should be noted that Kazakhstan has the highest availability of croplands among the CU member-countries. For example, availability of croplands in Kazakhstan is approximately amounted to 1.5 hectares per capita while in Russia this indicator is 1.8 times lower, and in Belarus-3.6 times (Grigoruk \& Nikitina, 2011).

At the same time, today there is a whole complex of problems which are slowing down the development of agro-industrial complex of Kazakhstan and negatively influencing its competitiveness in the world and regional markets.

Considering competitive advantages or disadvantages of agrarian and industrial complex of Kazakhstan within the CU, it should be noted that each member-country of the CU has its own structure of agricultural products, caused by objective distinctions in climatic conditions. So, climatic conditions of Kazakhstan are more severe in comparison with Russia and Belarus. Features of our region are: climate aridity, low amount of precipitations (the average annual precipitation in Kazakhstan is $250-300 \mathrm{~mm}$, whereas in Russia it is almost twice higher than in Kazakhstan (450-500 mm a year (Kaliyev, 2013)), and in Belarus the average annual precipitation is 650-700 $\mathrm{mm}$ ), and also desertification and degradation of lands.

Also it should be noted that despite high availability of lands, there is a problem of their irrational use. In 2013 the main share of cultivated areas ( $75 \%$ of total area) was taken for grain and leguminous crops (in comparison with 2012 their share decreased almost by 2\%), whereas the scientifically based norms of land use for grain-growing are specified in the range of $45-50 \%$ (Data of Statistics Committee of the Ministry of National Economy of the RK, 2014).

In turn, the share of seeds of potatoes, vegetables, melons and gourds, and forage crops in total area of seeding still remains insignificant (in total their share amounted to $15.4 \%$ of the general share of seeding). This situation negatively influences the country's availability of vegetables and fruits of own production, creates conditions for increasing the dependence on import of these products.

Insignificant share of seeds of forage lands together with their low yields negatively influence a livestock branch of the country. Today Kazakhstan produces in small volumes such feeding-stuff as haylage, monofeed (grain-haylage) and feeding beet. Production of succulent feed, necessary for livestock husbandry amounts only to $31 \%$ of the real need (Filatova, 2014).

Therefore, climatic conditions of Kazakhstan, climate aridity, low amount of precipitations, desertification of lands and their irrational use are the reasons of underrun of development indicators of the Kazakhstan agrarian and industrial complex from the Russian and Belarusian figurers, the low productivity of agriculture.

Also, one of the reasons of low productivity of Kazakhstan agriculture is wear of agricultural machinery. Despite the taken measures, country's agricultural machinery park has more than $80 \%$ wear. And this indicator is the highest among the $\mathrm{CU}$ member-countries. For instance, wear of agricultural machinery park in Russia and Belarus approximately amounted to $70 \%$.

In addition, there is a problem of insufficient equipment of Kazakhstan with agricultural machinery. So, according to the Department of Agriculture of the RK, in the republic 8.3 tractors is accounted for by 1000 hectares of arable land (at standards that 10.1 tractors is accounted for by 1000 hectares of arable land) while in Russia this indicator amounts to 10 tractors, in Belarus-19. The similar situation arosein connection with equipment of rural enterprises of the country with harvester thresher. 2.8 harvesters are accounted for by 1000 hectares of arable land, whereas in Russia and in Belarus 4.7 and 11 harvesters respectively are accounted for by 1000 hectares of arable land ("Analysis of production performance of agricultural and food products of the CU and the EEC member-countries for 2012-2013”, 2014).

High degree of wear of agricultural machinery is also a reason of decrease in diminishing of fertility, spread of diseases and crop pests, and reduction in yields. According to experts, the lack of basic types of equipment in 
good working condition leads to the increased reduction in yields which is estimated at $15-20 \%$ annually.

Efficiency of agricultural production is also an important indicator. In total, according to CU and EEC the level of output of agricultural production per 1 engaged amounts to 12.9 thousand USD. The leader in this point among the CU member-countries is the Republic of Belarus, where agricultural production per 1 engaged is equal to 25.5 thousand USD. In Kazakhstan this indicator is the lowest in CU and is equal to 5.7 thousand USD, whereas in Russia it is 2.5 times higher and amounted to 14.4 thousand USD. In the developed countries, such as the USA and Canada, average performance is higher than the Kazakhstan level in 30 and 23 times respectively ("Development level and Dynamics of Separate Segments of the Agrarian Market of the CU and the EEC", 2013).

One of the main instruments stimulating development of agrarian and industrial complex of the country is state support of agriculture and subsidizing of agricultural producers. High level of state support helps landowners with updating of agricultural machinery, allows them to buy and apply new technologies.

According to the Department of Agriculture of the RK, Kazakhstan considerably falls behind Russia and Belarus in volumes of state support in agricultural branch. So, the volume of state support in agriculture to the gross volume of actual agricultural products in Belarus amounts to $18 \%$, in Russia $-6 \%$ whereas in Kazakhstan this indicator is equal to $4 \%$, that is negatively reflects on country's agriculture development. The evidences of low level of state support are represented by the following data: in Kazakhstan 11 USD of state support is accounted for by 1 hectare of seeds-whereas in Russiathis indicator is equal to $30 \mathrm{USD}$, in Belarus-220 USD (Mamytbekov, 2013).

Besides public financing, investments play an important role in development of agrarian and industrial complex and increase of its competitiveness. Indicators of investment volumes attracted to the agro-industrial sphere of the RK show the lowest level of appeal of this sector to investments. Despite a growth tendency of volumes of investments into agrarian and industrial complex, their share in the total amount of investments in economy of Kazakhstan still remains very insignificant and fluctuates within 2.8-3.3\%, from 2009 to 2013 (Table 4).

Table 4. The volumes of investments into fixed assets for 2009-2013

\begin{tabular}{llllll}
\hline & $\mathbf{2 0 0 9}$ & $\mathbf{2 0 1 0}$ & $\mathbf{2 0 1 1}$ & $\mathbf{2 0 1 2}$ & $\mathbf{2 0 1 3}$ \\
\hline $\begin{array}{l}\text { Total volume of investments into fixed } \\
\text { assets, million KZT }\end{array}$ & $4,585,298$ & $4,653,528$ & $5,010,231$ & $5,473,161$ & $6,052,906$ \\
$\begin{array}{l}\text { The volume of investments into fixed } \\
\text { capital in agricultural, forest and fish } \\
\text { industries, million KZT }\end{array}$ & & 83,586 & 109,424 & 133,945 & 142,149 \\
$\begin{array}{l}\text { Volume of investments into fixed assets } \\
\text { of the food industry (production of } \\
\text { food, drinks and tobacco) }\end{array}$ & & & & \\
$\begin{array}{l}\text { Production of agricultural and forestry } \\
\text { machinery }\end{array}$ & 565.2 & 191.4 & $1,917.3$ & 2,054 & $2,347.6$ \\
$\begin{array}{l}\text { Share of investments into agrarian } \\
\text { and industrial complex in the total } \\
\text { amount of investments into fixed } \\
\text { assets, } \%\end{array}$ & $\mathbf{2 . 8}$ & $\mathbf{3 . 0}$ & $\mathbf{3 . 2}$ & $\mathbf{3 . 6}$ & $\mathbf{3 . 3}$ \\
\hline
\end{tabular}

Compiled by the author by Data of Statistics Committee of the Ministry of National Economy of the RK

The analysis of absolute and relative values of indicators of investment into agrarian and industrial complex of the RK testifies that investment of capital in domestic agribusiness isn't priority for investors. Thus, it should be noted that the share of investments into fixed assets of agrarian sector in Belarus amounts to $17 \%$, in Russia-more than $3 \%$.

The complex of above-mentioned problems in primary sectors of agrarian and industrial complex significantly reduces the resourcing of food industry of Kazakhstan, causes its insufficient level of development and inability to meet requirements of the local market. Respectively, the Kazakhstan products, with rare exception, are absent in Russian and Belarusian markets. According to experts, the reason interfering introduction and wide circulation 
of Kazakhstan food products and goods in the CU markets is a weak marketing policy and nonconformance of many goods to the quality standards, existing in the Russian Federation and the RB. Primarily, it refers to such goods of high export value as meat and meat products.

In spite of the fact that building of an export potential of Kazakhstan meat production is one of the priority directions of development of agriculture and non-oil export, practical realization of these tasks faces the following pressing issues:

- Small-marketability and low level of setup for production of the agricultural products accompanied with unsatisfactory quality of production. This issue is especially actual for kazakhstan as more than $70 \%$ of livestock inventory is contained in private subsidiary farming of population;

- Inefficient use of forage lands (only $30 \%$ of pastures are used), unsatisfactory condition of pastures and increased level of soil degradation;

- Low crop yield and unsatisfactory quality (low caloric content) of livestock feed and its insufficient quantity, expensiveness of livestock feed, that is one of the reasons of low efficiency of livestock production;

- Low efficiency of livestock production, which indicators are more times less than a level of developed countries, that is a consequence of a large number of nondescript cattle, insufficient volume and quality of livestock feed;

- Weak veterinary base, including imperfection in the field of legislative security; shortage of highly qualified personnel and low qualification of veterinarians; lack of veterinary laboratories and their weak material and technical base; imperfection in procedure of animals' identification.

Export of foodstuff, in its turn, is limited by the following issues:

- Nonconformance of technical characteristics of domestic production to norms and standards of foodstuff quality certification;

- High prime cost of foodstuff of kazakhstan production, which considerably lose the price competition with foreign productions (high product cost of kazakhstan products arise due to high tariffs for transport and railway transportations, utilities, high prices of raw materials while in prime cost of goods of other countries, for example, in the russian federation and belarus these indicators are much lower);

- Use of outdated production technologies and processing of production, low level of mechanization and automation of processes;

- Shortage of raw materials, necessary for the food industry, in consequence of which the domestic enterprises are compelled to import raw materials.

Thus, Kazakhstan has considerable potential in the market of agricultural products, primarily meat and cereals. Increased demand for these products on the world market provides opportunities for increase of the export potential of our country. Also, the production of milk and dairy products is very important for Kazakhstan as these products are the most important in the food market. Dynamics of production of the dairy industry in Kazakhstan has a positive trend and is able, according to experts, not only to meet domestic needs but also the needs of neighboring countries.

Also, a promising direction of RK AIC is a development of soy production. Soy is one of the most important crops of agriculture in many countries of the world. Soy production development in Kazakhstan contributes to solving the problems of protein malnutrition in human diets and animal nutrition. In addition, the development of soy production promotes crop diversification.

At the same time, the national agricultural production faces a number of systemic problems restraining its development and significantly restricts the ability to meet both domestic needs of Kazakhstan in food products, and, accordingly, the export obligation.

\section{Conclusion}

A small share of Kazakhstan in the CU food market and low competitiveness of domestic agriculture, in our opinion, is conditioned by the following factors:

- Insufficient and inefficient use of land and forage land (only 30\% of pastures are used). Despite the higher level of security of arable lands, pastures and hayfields, exceeding the performance of russia and belarus, the level of real gross agricultural production in kazakhstan many times behind the performance of these countries;

- Low yield and poor quality (low calorie) of fodders and insufficient amount of them, the high cost of fodders, 
which is one of the reasons for low productivity of livestock production;

- The low yield of grain and other crops, which is a consequence of the backwardness of the used technologies, insufficient level of development of agricultural science of rk, low implementation of innovation and $\mathrm{r} \& \mathrm{~d}$ achievements in the agricultural sector of kazakhstan, enabling to increase productivity and improve product quality;

- Poor infrastructure and high cost of transportation of agricultural products, a low level of logistics, which also affects the final price of kazakh products, reducing the competitiveness of rk producers;

- Low productivity of livestock production, which figures in times less than ones in developed countries, which is a consequence of a large number of nondescript cattle, small-scale production, insufficient volume and feeding quality;

- Low level of state support for agriculture, low investment and lending in comparison with its partners in the $\mathrm{cu}$;

- Obsolescence and physical deterioration of agricultural equipment (agricultural park as a whole has deterioration within $85 \%$ ), small-scale production and low level of organization of agricultural production and, consequently, low production efficiency;

- High cost of domestically produced goods, weak marketing policy and the non-compliance of many kazakhstani goods to standards and quality certificates, existing in the russian and belarusian markets, which prevents an increase in share of local products in the cu food market.

In order to increase the share of Kazakhstan in the $\mathrm{CU}$ food market and strengthen competitiveness of Kazakhstani products, in our opinion, it is necessary to:

- Improve the system of state support for agriculture, support system of agriculture producers and entrepreneurs by providing the subsidies, leasing and loans on favorable terms;

- Stimulate innovation and new technologies in agriculture;

- Establish a system of merchandising, develop agro marketing, improve the system of quality control, organize and unify the work of regulatory bodies;

- In order to improve and achieve conformity of domestic goods to quality standards that exist in the russian and belarusian market, and to prevent defective products in the kazakh market, it is necessary to improve the system of quality control, organize and unify the work of regulatory bodies;

- It's necessary to work out a system of monitoring and forecasting of cu markets of food and agricultural raw materials. The calculation of the so-called pre-emptive indicators will allow foreseeing a situation that may arise in different markets and develop a strategy and tactics of the behavior of market participants and the promotion of domestic products to foreign markets;

- Improve the efficiency of the negotiations between government agencies and agribusiness of three countries, stimulate their interaction.

Thus, taking into account these recommendations, as well as more focused work of various government departments and organizations on how to improve the competitiveness of Kazakhstan's agricultural products can significantly strengthen the position of Kazakhstan as a part of the $\mathrm{CU}$ food market and stimulate the development of domestic agriculture. Moreover, CU member states should strive to conduct a coordinated agrarian policy in its key points and directions.

\section{References}

Berentaev, K. B. (2013). Scientific and methodological and institutional-organizational problems of the Eurasian Union of States (pp. 13-48). Collection of scientific papers. KISS under the President of the Republic of Kazakhstan, Almaty.

Data of Statistics Committee of the Ministry of National Economy of the RK. (n.d.). Retrieved from http://stat.gov.kz/faces/wcnav_externalId/publBullS3-2013?_afrLoop=35432419917751\#\%40\%3F_afrLoop \%3D35432419917751\%26_adf.ctrl-state\%3D32xrhm858_103

Data of Statistics Committee of the Ministry of National Economy of the RK. (n.d.). Retrieved from http://stat.gov.kz/faces/wcnav_externalId/homeNumbersInvestment?_afrLoop=35945055581479\#\%40\%3F _afrLoop\%3D35945055581479\%26_adf.ctrl-state\%3D32xrhm858_173

Evdokimov, A. I. (2005). The challenges of globalization of the world economy: A monograph (p. 133). 
Sankt-Peterburg: StPSUoE.

Filatova, O. A. (2014). Report "Analysis of livestock branch" (pp. 23-26). Almaty: "Rating Agency of Almaty Regional Financial Centre" JSC.

Grigoruk, V. V., \& Nikitina, G. A. (2011). Kazakhstan in the food market of the Customs union (pp. 1-5). The VI international conference "The Customs union and the Common economic space of EurAsEC: Prospects of further integration", Almaty.

Kaliyev, G. A. (2013). On the problems of product competitiveness of the agricultural sector of Kazakhstan in terms of its accession to the WTO. Retrieved from http://www.gosbook.ru/node/80694

Kiselev, S. (2009). Regional integration as a defense mechanism against the challenges of globalization. Retrieved from http://www.kapital-rus.ru/index.php/articles/article/135268

Kuzovkov, J. (2010). "Theory of Globalization" in the trilogy "The Unknown Story". Retrieved from http://www.yuri-kuzovkov.ru/theory/globalizatsiya/

Libman, A. (2012). Studies of Regional Integration in the CIS and in Central Asia: A Literature Survey. Saint Petersburg: Centre for Integration Studies.

Report of EEC "Production performance of agriculture of the CU and the EEC member-countries at the end of the 1st half of 2014".

Report of the EEC "Development level and Dynamics of Separate Segments of the Agrarian Market of the CU and the EEC".

Statistical data of the Eurasian Economic Commission. Retrieved from http://www.eurasiancommission.org/ru/act/integr_i_makroec/dep_stat/test-trade/tables/Pages/default.aspx.

Structure of mutual trade of the CU and the EEC member-countries, data on the integrated commodity groups. (2014, January-July).

The report of EEC "Analysis of production performance of agricultural and food products of the $C U$ and the EEC member-countries for 2012-2013".

The report of the Minister of Agriculture of the RK, A. S. Mamytbekov, at government session of the RK. (n.d.). Retrieved from http://mgov.kz/doklad-ministra-sel-skogo-hozyajstva-rk-mamy-tbekova-a-s-nazasedanii-pravitel-stva-rk-v-selektornom-rezhime-po-voprosu-ob-itogah-uborki-urozhaya-i-situatsii-na-ry-n ke-zerna-12-11-13-g/

Vladimirov, I. G. (2001). Globalization of the World Economy: Challenges and Implications. Retrieved from http://www.cfin.ru/press/management/2001-3/10.shtml

Wallerstein, I. (2000). Globalization or the age of transition? A long-term view of the trajectory of the world system. International Sociology, 15(2). http://dx.doi.org/10.1177/0268580900015002007

\section{Copyrights}

Copyright for this article is retained by the author(s), with first publication rights granted to the journal.

This is an open-access article distributed under the terms and conditions of the Creative Commons Attribution license (http://creativecommons.org/licenses/by/3.0/). 